\title{
Regulatory T Cells in Mycobacterium tuberculosis Infection
}

\author{
Paula Cardona and Pere-Joan Cardona* \\ Unitat de Tuberculosi Experimental, Fundació Institut Germans Trias i Pujol, CIBER Enfermedades Respiratorias, Universitat \\ Autònoma de Barcelona, Badalona, Spain
}

Anti-inflammatory regulatory $T$ cells have lately attracted attention as part of the immune response to Mycobacterium tuberculosis infection, where they counterbalance the protective but pro-inflammatory immune response mediated by Th17 cells and especially by the better-known Th1 cells. In chronic infectious diseases there is a delicate balance between pro- and anti-inflammatory responses. While Th1 and Th17 are needed in order to control infection by Mycobacterium tuberculosis, the inflammatory onset can ultimately become detrimental for the host. In this review, we assess current information on the controversy over whether counterbalancing regulatory $T$ cells are promoting pathogen growth or protecting the host.

\section{OPEN ACCESS}

Edited by:

Julio Aliberti,

National Institute of Allergy and Infectious Diseases (NIAID),

United States

Reviewed by:

Andre Bafica,

Federal University of Santa

Catarina, Brazi

Kevin Urdahl,

Seattle Biomedical Research Institute,

United States

Warwick Britton,

University of Sydney, Australia

*Correspondence:

Pere-Joan Cardona

pj.cardona@gmail.com

Specialty section:

This article was submitted to

Microbial Immunology,

a section of the journal

Frontiers in Immunology

Received: 06 May 2019

Accepted: 27 August 2019

Published: 11 September 2019

Citation:

Cardona P and Cardona P-J (2019)

Regulatory T Cells in Mycobacterium

tuberculosis Infection.

Front. Immunol. 10:2139.

doi: 10.3389/fimmu.2019.02139

Keywords: tuberculosis, Treg cells, Th17 cells, tolerance, inflammation

\section{INTRODUCTION}

Tuberculosis (TB) is a global disease caused by the bacillus Mycobacterium tuberculosis (Mtb). According to the World Health Organization, in 2017, 10 million people developed the disease and 1.6 million people died because of it (1). Compounding the situation, approximately a quarter of the world population is currently infected with Mtb (latent TB infection: LTBI) (2).

While progression from Mtb infection to active TB is associated with some known risk factors, including HIV infection and malnutrition, it is still unclear why some apparently healthy people develop the disease. One hypothesis is that poor control of the inflammatory response is the culprit. While an effective immune response is essential to control the infection at an early stage, excessive inflammation may be detrimental later on. The damage-response framework of microbial pathogenesis (3) suggests that both ends of the scale would lead to the development of the disease, where a weak response would benefit the dissemination of the bacilli and a very strong response would favor the lung tissue damage characteristic of active TB. The fact that the majority of cases of Mtb infection develop as LTBI imply that most individuals have intermediate response levels (4). There are diverse studies pointing to the immune balance and the development of TB. The modulation of the leukotriene A4 hydrolase locus, which is key in the balance between pro- and anti-inflammatory eicosanoids, showed to be important in the regulation of TNF- $\alpha$ levels, and thus in the susceptibility to Mtb $(5,6)$. Interestingly, these authors showed that among individuals with meningitis TB, both homozygous forms of a specific genotype affecting this locus were related to a decreased survival of patients, supporting the idea that both a low and high inflammatory response may be detrimental.

This double-edged nature of the immune response also comes into play in the concept of disease tolerance, a host defense strategy in which less damage is done by the pathogen or the immune response it triggers, although the burden of the microorganism itself is not reduced. In this context, immunosuppressive mechanisms are seen as one of the ways in which the host achieves tolerance (7). Regulatory T cells (Tregs), which suppress, and thus counterbalance the inflammatory response, are one such mechanism. 
There is a recurring debate as to whether Tregs are beneficial or detrimental in Mtb infection. Many studies, mainly of blood samples, show higher numbers of Tregs in TB patients than in LTBI subjects or healthy controls. Some of these studies also focus on the follow-up of TB patients undergoing treatment. However, it is not yet clear whether high levels of Tregs are a consequence of inflammation or a risk factor for development of TB. After briefly introducing Tregs, the present review will address this question by examining the available data from animal models and human subjects.

\section{REGULATORY T CELL CHARACTERIZATION}

The immune system has mechanisms for suppressing the response to persistent self- or non-self-antigens. Tregs are a lymphocyte subset whose main role is maintaining immune homeostasis and peripheral tolerance.

The key cytokines involved in the immunosuppressive function of Tregs are IL-10, TGF- $\beta$, and IL-35 (8-10). By downmodulating the co-stimulatory molecules CD80 or CD86 in a CTLA-4-dependent mechanism, Tregs interfere with T-cell activation by dendritic cells (11). Tregs also express granzymes and thus induce apoptosis of the target cells (12). Another mechanism of suppression is metabolic disruption, achieved by consuming available IL-2 (13).

Tregs might be induced in the thymus during development (tTregs) or in peripheral tissue such as mucosa (pTregs). Research on therapies that modulate these cells, or the administration of in vitro induced Tregs (iTregs), have led to efforts to differentiate them (14). tTregs generally target auto-antigens, are more stable, and have higher TCR affinity. The expression of the transcription factor Helios has been linked to tTregs (15) since it is detected in all the $\mathrm{CD}^{+}{ }^{+} \mathrm{FoxP}^{+}$thymocytes, but only in around $70 \%$ of $\mathrm{CD}^{+}{ }^{+} \mathrm{FoxP}^{+}$from peripheral lymphoid tissues. The high expression of the surface marker Neuropilin 1, which is upregulated by TGF- $\beta$, has also been considered as a tTregs marker (16). Interestingly, it had been previously shown that the induction of pTregs, but not tTregs, is dependent on this cytokine (17). Neither of these markers clearly identifies the thymic induced Tregs from pTregs or iTregs.

\section{Treg Phenotype Markers}

Identification of an optimal cellular marker for characterizing Tregs in general is also proving difficult. Some markers used, in combination with CD3 and CD4, include CD25, FoxP3, CD127, or CD39. Although $\mathrm{CD}^{+}$Tregs have also been described, as recently reviewed by $\mathrm{Yu}$ et al. (18), they have not been considered in the present review.

CD25 is highly expressed in Tregs and is in fact related to one of the suppression mechanisms of these cells. However, this extracellular marker, which is the $\alpha$-chain of the high affinity receptor for IL-2, is also upregulated in activated T cells (19). Therefore, it is generally used in combination with other markers.

FoxP3 is a transcription factor, Forkhead box P3, long used as a marker for Tregs, since it is essential for their development (20).
IPEX (immune dysregulation, polyendocrinopathy, enteropathy, $\mathrm{X}$-linked) syndrome is an autoimmune disease caused by mutations in FoxP3 that lead to Treg dysfunction (21). This mutation has also been described in scurfy mice, which have high lymphocytic infiltration resulting in death after a few weeks (22). Nevertheless, FoxP3 has also been associated with other cell types (23), and T cells with regulatory properties that do not express it have also been described (24), so the case for using it as a marker is considerably weakened. Besides, working with an intracellular marker is less appealing and often impractical, since it interferes with functional assays.

In the case of CD127, the $\alpha$ chain of the IL-7 receptor, low to undetectable expression levels have also been used to identify Tregs among $\mathrm{CD} 4{ }^{+} \mathrm{CD} 25^{+}$cells (25). This marker is downregulated in $\mathrm{T}$ cells after activation and re-expressed in all but FoxP ${ }^{+}$cells. FoxP3 interacts with the promoter CD127 and represses it (26).

CD39 is an ectonucleotidase that turns ATP or ADP into $\mathrm{AMP}$ and is expressed by $\mathrm{CD} 4^{+} \mathrm{CD} 25^{+}$and $\mathrm{CD}^{+}{ }^{+} \mathrm{FoxP}^{+}$ cells. This has a dual anti-inflammatory effect: it eliminates the inflammatory mediator ATP and increases production of adenosine, which inhibits the NK- and T-cell response (27). Characterization of $\mathrm{CD} 4{ }^{+} \mathrm{CD} 25^{+} \mathrm{CD} 127^{-}$Tregs from peripheral blood mononuclear cells (PBMCs) according to CD39 expression showed that CD39hi Tregs secrete more IL-10 and have a stronger suppressive activity. Moreover, in the presence of IL$1 \beta$ and IL-6, CD39 ${ }^{\text {low }}$ Tregs differentiated into Th1 or Th17 and down-regulated the expression of FoxP3 as compared to CD39hi Tregs (28). Further supporting the use of CD39 to characterize a regulatory T-cell phenotype, it has been described that $\mathrm{CD} 4{ }^{+} \mathrm{CD} 25^{\mathrm{hi}} \mathrm{CD} 39^{+}$cells produce lower levels of IFN $-\gamma$ and higher of TGF- $\beta$ than $\mathrm{CD} 4{ }^{+} \mathrm{CD} 25^{\text {hi }} \mathrm{CD} 39^{-}$cells or $\mathrm{CD} 4^{+} \mathrm{T}$ cells with low or no expression of CD25 (29).

\section{Th17-Counterbalancing Role}

Th17 cells are characterized mainly by the production of IL17, which promotes the synthesis of other pro-inflammatory cytokines, and chemokines (30). The transcription factor required for the development of Th17 cells is ROR $\gamma \mathrm{t}$ (31).

Tregs and Th17 cells are closely intertwined. TGF- $\beta$ induces both FoxP3 and ROR $\gamma$ t expression; however, in order to induce Th17, TGF- $\beta$ also requires the presence of IL-6, in which case the balance is tipped toward Th17 cells instead of Tregs (32). Otherwise, FoxP3 inhibits the function of ROR $\gamma \mathrm{t}$ (33). It has been shown that $\mathrm{CD} 4{ }^{+} \mathrm{CD} 25^{\text {hi }} \mathrm{CD} 39^{+}$Tregs have a role in constraining pathogenic Th17 cells (34).

\section{TREGS AND DISEASE}

Tregs have been linked to a number of inflammatory diseases, mostly autoimmune but some of them infectious. Equilibrium with Th17 cells is widely thought to be the key factor in these conditions, but this review will focus on Tregs.

Multiple sclerosis, a chronic autoimmune inflammatory disease of the central nervous system, has been related to an increase in the number and activity of pro-inflammatory Th17 cells and a corresponding decrease in Tregs (35). Rheumatoid 
arthritis, also of autoimmune origin, affects synovial tissue, where an imbalance has been reported between Tregs and Th17 cells (36).

The relevance of the balance between these cell populations was shown in a Treg phenotyping study carried out in PBMCs in the context of organ transplants. Renal allograft rejection was associated with a high ratio of $\mathrm{CD} 4{ }^{+} \mathrm{CD} 25^{-} \mathrm{CD} 39^{+}$ cells, which have a pro-inflammatory memory profile, to $\mathrm{CD} 4{ }^{+} \mathrm{CD} 25^{+} \mathrm{CD} 39^{+}$Tregs (37).

High levels of Tregs have been associated with different types of cancer, both in peripheral blood samples, and in solid tumors. However, their precise role in cancer is still undefined, with some researchers linking higher levels to a favorable outcome, and others to a poorer prognosis. In addition to these differences in number, higher Treg suppressive activity has also been described in cancer cases (38).

Another area of study is the relationship between Tregs and different pathogens. In Helicobacter pylori infection, increased Treg frequency appears to help limit damage due to inflammatory onset, but it also promotes bacterial growth (39). This pattern is quite common and applies to a number of different pathogens, including viruses $(40,41)$.

The two-edged action of Tregs also plays a role in Mtb infection. The pro-inflammatory response characterized by the production of IFN- $\gamma$ or IL-17 is necessary to control Mtb growth, so Tregs would appear to be detrimental in terms of countering the pathogen. However, if left unchecked, the inflammatory response ultimately causes excessive tissue damage to the host. Tables 1, 2 summarize TB-related research with a focus on Tregs. These studies of animal models and human cohorts are discussed below separately.

\section{Tregs in TB Animal Models}

In the guinea pig model, while studying the pathogenicity of different Beijing sublineages of Mtb, it was shown that highly virulent strains have increasing levels of FoxP3, IL-10, and TGF$\beta$ mRNA in lung tissue as infection progresses (42). In another study with a similar focus, FoxP3, and TGF- $\beta$ expression was also found to increase in the lungs with progression of infection, but pro-inflammatory IL-17 increased as well. With less virulent strains, the increase is not as steep (43).

Results from a non-human primate (NHP) Mtb infection model suggest that augmented Treg levels are a response to inflammation, rather than the cause of TB disease (44). These authors found that NHPs that failed to develop TB disease (i.e., LTBI cases) had higher levels of Tregs in peripheral blood prior to infection than those that developed active TB. Although all subjects experienced an initial decrease in Treg frequencies, animals that remained latently infected remained at higher levels during the period of decline and eventually returned to preinfection levels as infection progressed, while Tregs continued to increase in the NHPs with TB. In a separate study, IL-2 treatment of NHP in early-stage infection expanded Foxp3 ${ }^{+}$ Tregs, and $\mathrm{CD} 4^{+} / \mathrm{CD}^{+} / \gamma \delta \mathrm{T}$ effector cells (45). The authors linked ensuing resistance to severe TB lesions to an optimal cooperation between IL-2-expanded CD4 ${ }^{+} \mathrm{T}$ cells and Tregs, by preventing overreacting inflammatory responses.
In a murine model, when $\mathrm{CD} 25^{+}$cells were depleted in DBA/2 mice prior to Mtb aerosol infection, infection outcomes improved: there was a reduction in the bacillary load (BL) of lungs and spleen, together with less severe histopathology in the lungs (46). Nevertheless, this effect was seen only at week 2 postinfection, and afterwards there was no difference between groups. There was also no significant effect if $\mathrm{CD}_{2} 5^{+}$cell depletion was done at the chronic stage of infection. Similar results were observed using a mixed bone chimera system where FoxP3 ${ }^{+}$ cells were depleted with anti-Thyl.1 antibodies: there was a reduction in $\mathrm{BL}$ in the lungs, but not the spleen, at day 23 post-infection (47).

However, depletion of $\mathrm{CD} 25^{+}$cells 3 days prior to infection in both $M$. bovis BCG- and Mtb-infected C57BL/6 mice had no effect on $\mathrm{BL}$, even though a reduction in $\mathrm{CD} 4^{+} \mathrm{CD} 25^{+}$ cells was observed for at least 23 days (48). In fact, the characterization of two mouse strains with the same haplotype but different susceptibility to $\mathrm{Mtb}$ infection $(\mathrm{C} 3 \mathrm{HeB} / \mathrm{FeJ}$ and $\mathrm{C} 3 \mathrm{H} / \mathrm{HeN}$ ) showed that the more susceptible animals had lower numbers of Tregs (49). Furthermore, after $\mathrm{CD} 25^{+}$cells were depleted in the more resistant strain, lung pathology became more severe. Another study in two mouse strains with different susceptibility, the hyper-susceptible I/StSnEgYCit and the relatively resistant $\mathrm{C} 57 \mathrm{BL} / 6 \mathrm{JCit}$, showed that Treg levels were lower in the mediastinal lymph nodes of the susceptible mice and remained practically constant during the follow-up period (until week 17 post-infection), while this cell population increased over time in the resistant C57 mice. The authors concluded that this is a host protective strategy (50).

Scott-Browne et al. (47) failed to see a similar percentage increase, but did find an increase in total numbers of $\mathrm{CD}^{+}{ }^{+} \mathrm{FoxP}^{+}$cells in the lungs and pulmonary lymph nodes (pLN) of Mtb-infected C57BL/6 mice. However, they were unable to detect production of the characteristic regulatory cytokine IL-10 by this cell population in vitro. These same researchers (51) showed that Tregs expand both in lungs and pLN; but this occurs after Mtb has been transported to pLN, same as effector T cells. The adoptive transfer of Mtb-specific Tregs $\left(\mathrm{CD} 4{ }^{+} \mathrm{CD} 25^{+}\right)$ before $\mathrm{T}$ cell expansion results in higher BL, but no effects were seen when using non-specific Tregs or specific effector cells. In a later study, the authors found that the Mtb-specific Treg expansion is higher in pLN, but these cells have a short-life, and do not accumulate as infection progresses (52). These FoxP3 ${ }^{+}$ cells form pLN have a high expression of the transcription factor Helios and expand from cells already expressing FoxP3 ${ }^{+}$, suggesting they are thymically derived. The reduction in the Treg levels would be mediated by the transcription factor T-bet in an IL-12 dependent manner.

Contrary to these observations, a reduction in the frequency of Tregs in lungs after infection was described by McBride et al. (53) in both toll-like receptor 2 (TLR2) knockout mice (C57BL/6 strain) and their wild-type counterparts, although less in the former, which had a higher BL. In this study, the authors demonstrated that TLR2 activation on myeloid cells is necessary to induce the accumulation of $\mathrm{CD} 4^{+} \mathrm{FoxP}^{+}$in the lungs, and that these accumulated Tregs prevent immunopathology and associated tissue damage. This suggested that Tregs may function 
TABLE 1 | Summary of data on Tregs and TB from animal models.

\begin{tabular}{|c|c|c|c|c|}
\hline Animal model & Sample & Treg phenotype & Relationship between Tregs and TB & References \\
\hline $\begin{array}{l}\text { Guinea pig, aerosol infection with Mtb H37Rv } \\
\text { and Erdman laboratory strains, and } 3 \text { clinical } \\
\text { isolates of Mtb }\end{array}$ & Lungs & FoxP3 mRNA & Progression of infection increases Treg levels & $(42)$ \\
\hline $\begin{array}{l}\text { Guinea pig, aerosol infection with clinical } \\
\text { isolates of Mtb Beijing strains }\end{array}$ & Lungs & FoxP3 mRNA & Progression of infection increases Treg levels & $(43)$ \\
\hline \multirow[t]{2}{*}{$\begin{array}{l}\text { Cynomolgus Macaque, bronchoscopic } \\
\text { instillation infection with Mtb Erdman strain }\end{array}$} & $\begin{array}{l}\text { Lungs } \\
\text { and LNs }\end{array}$ & $\mathrm{CD}^{+} \mathrm{CD}^{+}{ }^{+} \mathrm{FoxP}^{+}$ & $\begin{array}{l}\text { Higher levels of Tregs in Mtb-positive lungs and } \\
\text { draining LNs }\end{array}$ & $(44)$ \\
\hline & PBMCs & & $\begin{array}{l}\text { Higher levels of Tregs found prior to infection in } \\
\text { animals that did not develop the disease }\end{array}$ & \\
\hline \multirow[t]{2}{*}{$\begin{array}{l}\text { Cynomolgus Macaque, bronchoscopic } \\
\text { instillation infection with Mtb Erdman strain }\end{array}$} & Blood & $\mathrm{CD}^{+}{ }^{+} \mathrm{CD}_{25}{ }^{+} \mathrm{FoxP}^{+}$ & $\begin{array}{l}\text { Higher levels of Tregs correlates with less } \\
\text { severe lung pathology after IL-2 treatment }\end{array}$ & $(45)$ \\
\hline & BAL & & & \\
\hline $\begin{array}{l}\text { DBA/2 mice, aerosol infection with Mtb Kurono } \\
\text { or Erdman strains }\end{array}$ & Systemic & $\mathrm{CD} 25^{+}$ & $\begin{array}{l}\text { Treg depletion decreases spleen and lung BL } \\
\text { and improves lung pathology (at early stages of } \\
\text { infection) }\end{array}$ & $(46)$ \\
\hline \multirow[t]{2}{*}{$\begin{array}{l}\text { C57BL/6 \& bone marrow chimeric mice, } \\
\text { aerosol infection with Mtb H37Rv strain }\end{array}$} & $\begin{array}{l}\text { Lungs } \\
\text { and LNs }\end{array}$ & $\mathrm{CD}^{+}{ }^{+} \mathrm{FoxP}^{+}$ & $\begin{array}{l}\text { Progression of infection increases Treg levels } \\
\text { (WT) }\end{array}$ & $(47)$ \\
\hline & Systemic & $\mathrm{FoxP}^{+}$ & Treg depletion decreases lung BL & \\
\hline $\begin{array}{l}\text { C57BL/6, aerosol infection with Mtb Erdman } \\
\text { strain }\end{array}$ & Systemic & $\mathrm{CD}^{2} 5^{+}$ & $\begin{array}{l}\text { Treg depletion does not affect BL or lung } \\
\text { pathology }\end{array}$ & $(48)$ \\
\hline \multicolumn{5}{|l|}{$\begin{array}{l}\text { C57BL/6, intranasal infection with M. bovis } \\
\text { BCG Pasteur strain 1173P2 }\end{array}$} \\
\hline \multirow[t]{2}{*}{$\begin{array}{l}\text { C3HeB/FeJ \& C3HeN, intravenous infection } \\
\text { with Mtb H37Rv Pasteur strain }\end{array}$} & Spleen & $\mathrm{CD}^{+}{ }^{+} \mathrm{CD}_{25}{ }^{+} \mathrm{FoxP}^{+}$ & $\begin{array}{l}\text { Higher levels of Tregs in strain less susceptible } \\
\text { to infection }(\mathrm{C} 3 \mathrm{HeN})\end{array}$ & $(49)$ \\
\hline & Systemic & $\mathrm{CD}_{25}^{+}$ & $\begin{array}{l}\text { Treg depletion exacerbates lung pathology } \\
(\mathrm{C} 3 \mathrm{HeN})\end{array}$ & \\
\hline \multirow[t]{2}{*}{$\begin{array}{l}\text { I/StSnEgYCit and C57BL/6JCit mice, aerosol } \\
\text { infection with Mtb H37Rv Pasteur strain }\end{array}$} & $\begin{array}{l}\text { Mediastinal } \\
\text { LNs }\end{array}$ & $\mathrm{CD}^{+}{ }^{+} \mathrm{CD}_{25}{ }^{+} \mathrm{FoxP}^{+}$ & $\begin{array}{l}\text { Higher levels of Tregs found in strain less } \\
\text { susceptible to infection (C57BL/6JCit) }\end{array}$ & $(50)$ \\
\hline & & & $\begin{array}{l}\text { Progression of infection increases Treg levels } \\
\text { (C57BL/6JCit) }\end{array}$ & \\
\hline $\begin{array}{l}\text { C57BL/6 \& P25 TCR transgenic mice, aerosol } \\
\text { infection with Mtb H37Rv strain }\end{array}$ & Systemic & $\mathrm{CD} 4^{+} \mathrm{CD}_{25}+$ & $\begin{array}{l}\text { Mtb-specific Treg adoptive transfer increases } \\
\text { BL }\end{array}$ & $(51)$ \\
\hline $\begin{array}{l}\text { C57BL/6, FoxP3-GFP reporter \& TCR KO } \\
\text { mice, aerosol infection with Mtb H37Rv strain }\end{array}$ & $\begin{array}{l}\text { Pulmonary } \\
\text { LN }\end{array}$ & $\mathrm{CD}^{+}{ }^{+} \mathrm{FoxP}^{+}$ & $\begin{array}{l}\text { Early expansion of Mtb-specific thymically } \\
\text { derived Tregs }\end{array}$ & $(52)$ \\
\hline $\begin{array}{l}\text { C57BL/6 \& IL-12p35 or IL12p40 KO mice, } \\
\text { aerosol infection with Mtb H37Rv strain }\end{array}$ & & & $\begin{array}{l}\text { Progression of infection decreases Mtb-specific } \\
\text { Tregs in an IL-12 dependent manner }\end{array}$ & \\
\hline \multirow{2}{*}{$\begin{array}{l}\text { C57BL/6 \& TLR2 KO mice, aerosol infection } \\
\text { with Mtb Erdman strain }\end{array}$} & Lungs & $\mathrm{CD}^{+}{ }^{+} \mathrm{FoxP}^{+}$ & Progression of infection decreases Treg levels & $(53)$ \\
\hline & & & $\begin{array}{l}\text { KO have fewer Tregs than WT after infection, } \\
\text { and higher } B L\end{array}$ & \\
\hline $\begin{array}{l}\text { C57BL/6, BALB/c, DBA/2 mice, aerosol } \\
\text { infection with clinical isolate of Mtb Harlingen } \\
\text { strain }\end{array}$ & Lungs & $\mathrm{CD}^{+}{ }^{+} \mathrm{FoxP}^{+}$ & $\begin{array}{l}\text { Higher levels of Tregs found in strains less } \\
\text { susceptible to infection (C57BL/6 and BALB/c) }\end{array}$ & $(54)$ \\
\hline $\begin{array}{l}\text { C57BL/6, aerosol infection with Mtb H37Rv } \\
\text { strain }\end{array}$ & Systemic & $\mathrm{CD}^{+}{ }^{+} \mathrm{CD}_{25}{ }^{+} \mathrm{FoxP}^{+}$ & $\begin{array}{l}\text { Treg depletion does not interfere with BCG } \\
\text { effect }\end{array}$ & $(55)$ \\
\hline $\begin{array}{l}\text { C57BL/6, aerosol infection with Mtb Erdman } \\
\text { strain or } M \text {. bovis Wag201 strain }\end{array}$ & Systemic & $\mathrm{CD}_{25}^{+}$ & $\begin{array}{l}\text { Treg depletion has no effect on BCG-mediated } \\
\text { reduction of BL and improves lung pathology }\end{array}$ & $(56)$ \\
\hline \multirow[t]{2}{*}{$\begin{array}{l}\text { BALB/c, intratracheal infection with Mtb H37Rv } \\
\text { strain }\end{array}$} & Lungs & $\mathrm{CD}^{+}{ }^{+} \mathrm{FoxP}^{+}$ & $\begin{array}{l}\text { Lower number of Tregs correlate with better } \\
\text { vaccine protection }\end{array}$ & $(57)$ \\
\hline & Systemic & $\mathrm{CD}^{2} 5^{+}$ & $\begin{array}{l}\text { Treg depletion does not interfere with vaccine } \\
\text { effect }\end{array}$ & \\
\hline
\end{tabular}

BAL, bronchoalveolar lavage; BL, bacillary load; KO, knock-out; LN, lymph node; PBMCs, peripheral blood mononuclear cells; WT, wild-type.

by restraining the influx of monocytes and neutrophils, serving to limit the availability of niches for Mtb to replicate. In this study authors were not able to discern whether the increased
BL was caused by the absence of TLR2-mediated antimicrobial activity in the granuloma or by enhanced inflammation. The latter hypothesis would support the findings in the NHP model 
TABLE 2 | Summary of data on Tregs and TB from human cohorts.

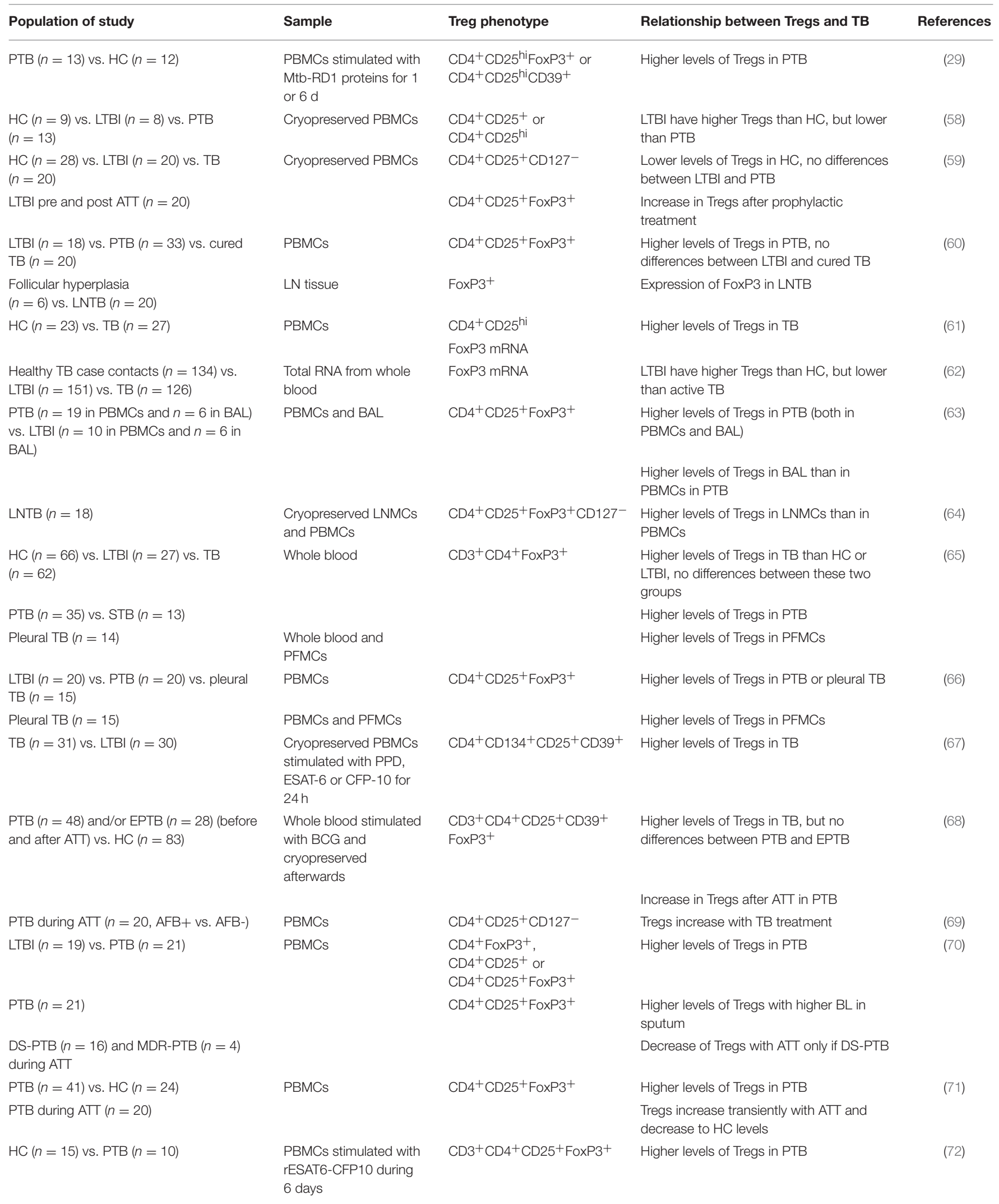


TABLE 1 | Continued

\begin{tabular}{|c|c|c|c|c|}
\hline Population of study & Sample & Treg phenotype & Relationship between Tregs and TB & References \\
\hline PTB during ATT $(n=10)$ & & & Treg decrease with ATT & \\
\hline PTB $(n=15)$ vs. $\mathrm{HC}(n=17,41 \%$ QTF +$)$ & $\begin{array}{l}\text { PBMCs cultured } \\
\text { overnight }\end{array}$ & $\begin{array}{l}\mathrm{CD}^{+}{ }^{+} \mathrm{CD} 25^{+} \mathrm{CD} 39^{+} \text {or } \\
\mathrm{CD}^{+}{ }^{+} \mathrm{CD} 25^{+} \mathrm{FoxP}^{+}\end{array}$ & $\begin{array}{l}\text { Higher levels of Tregs in PTB, no } \\
\text { differences between QTF+ and QTF- }\end{array}$ & (73) \\
\hline PTB during ATT $(n=12)$ & & & Treg levels decrease with ATT & \\
\hline $\begin{array}{l}\text { HC }(n=15) \text { vs. PTB }(n=13) \text { vs. } \\
\text { completed ATT }(n=21)\end{array}$ & $\begin{array}{l}\text { PBMCs cultured } \\
\text { overnight }\end{array}$ & $\begin{array}{l}\mathrm{CD}^{+}{ }^{+} \mathrm{CD} 25^{+} \mathrm{CD} 39^{+} \text {or } \\
\mathrm{CD}^{+}{ }^{+} \mathrm{CD}^{+} 5^{+} \text {FoxP3 }^{+}\end{array}$ & $\begin{array}{l}\text { Higher levels of Tregs in PTB than } \mathrm{HC} \text { and } \\
\text { cured TB. Treatment failure: increase in } \\
\text { Tregs }\end{array}$ & $(74)$ \\
\hline $\begin{array}{l}\text { LTBI }(n=10) \text { vs. PTB }(n=10) \text { vs. cured } \\
\text { TB }(n=10)\end{array}$ & $\begin{array}{l}\text { PBMCs stimulated with } \\
\text { M. bovis antigens for } \\
48 \mathrm{~h}\end{array}$ & $\mathrm{CD}^{+}{ }^{+} \mathrm{CD}_{25} 5^{\text {hi }}$ FoxP3 ${ }^{+}$ & Lower levels of Tregs in LTBI & $(75)$ \\
\hline $\begin{array}{l}\text { HC }(n=80) \text { vs. LTBI }(n=80) \text { vs. PTB } \\
(n=90)\end{array}$ & PBMCs & $\mathrm{CD}^{+}{ }^{+} \mathrm{CD} 25^{+} \mathrm{C}_{12} 7^{-}$ & $\begin{array}{l}\text { LTBI have higher Tregs than } \mathrm{HC} \text {, but lower } \\
\text { than PTB }\end{array}$ & (76) \\
\hline $\begin{array}{l}\text { PTB }(n=30) \text { vs. cured TB }(n=10) \text { or HC } \\
(n=30)\end{array}$ & Whole blood & $\begin{array}{l}\mathrm{CD}^{+}{ }^{+} \mathrm{CD}_{25} 5^{+} \text {or } \\
\mathrm{CD}^{+}{ }^{+} \mathrm{CD} 25^{+} \mathrm{FoxP}^{+}\end{array}$ & Higher levels of Tregs in PTB & $(77)$ \\
\hline $\mathrm{AFB}+(n=21)$ vs. AFB $-(n=9)$ & & & Higher levels of Tregs in AFB + & \\
\hline $\begin{array}{l}\text { Cavitary TB }(n=19) \text { vs. non-cavitary TB } \\
(n=11)\end{array}$ & & & Higher levels of Tregs in cavitary PTB & \\
\hline $\begin{array}{l}\text { HC }(n=14) \text { vs. DS-PTB }(n=33) \text { vs. } \\
\text { MDR-PTB }(n=7) \text { vs. stable MDR-PTB } \\
(n=16)\end{array}$ & PBMCs & $\mathrm{CD}^{+}{ }^{+} \mathrm{FoxP}^{+}$ & $\begin{array}{l}\text { Higher levels of Tregs in active PTB (DS or } \\
\text { MDR), no differences between stable } \\
\text { MDR-PTB and HC }\end{array}$ & (78) \\
\hline $\begin{array}{l}\text { HC/LTBI }(n=20) \text { vs. DS-PTB }(n=20) \text { vs. } \\
\text { MDR-PTB }(n=18)\end{array}$ & PBMCs & $\mathrm{CD}^{+}{ }^{+} \mathrm{CD}_{25}{ }^{+} \mathrm{FoxP}^{+}$ & $\begin{array}{l}\text { Higher levels of Tregs in DS-PTB than } \\
\text { HC/LTBI, but lower than MDR-PTB }\end{array}$ & (79) \\
\hline $\begin{array}{l}\text { HC }(n=30) \text { vs. DS-TB }(n=30) \text { vs. } \\
\text { MDR-TB }(n=30)\end{array}$ & PBMCs & $\mathrm{CD} 4^{+} \mathrm{CD} 25^{+}$ & $\begin{array}{l}\text { Higher levels of Tregs in DS-TB than HC, } \\
\text { but lower than MDR-TB }\end{array}$ & (80) \\
\hline
\end{tabular}

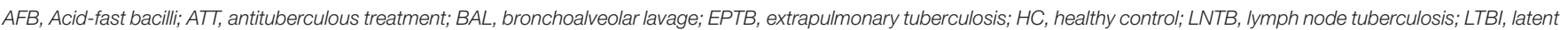

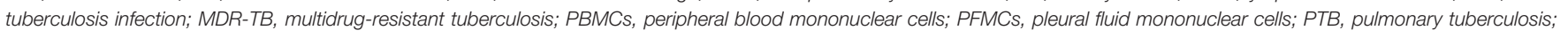
QTF, quantiferon; STB, severe tuberculosis (PTB with meningitis).

(44) and the idea that Tregs and T effector cells act together to control inflammation without increasing Mtb replication (45). In another study, the lungs of $\mathrm{Mtb}$-infected resistant mouse strains (C57BL/6 and $\mathrm{BALB} / \mathrm{c}$ ), compared to the $\mathrm{DBA} / 2$ susceptible strain, had higher numbers of Tregs as well as of $\mathrm{CD} 103^{+}$ dendritic cells, which showed an anti-inflammatory profile (54).

The concern that Tregs might interfere with the protective effect of BCG vaccination has been addressed. C57BL/6 mice were administered an adenoviral vector that expresses murine IL-28B, which is thought to down-regulate Tregs. When this was given together with BCG and a subunit vaccine booster, Tregs were depleted in the spleen but this had no influence on the effects of vaccination (55). These results support what was previously observed by Quinn et al. (56), who inactivated Tregs with anti-CD25 $\mathrm{mAb}$ prior to vaccination and found that this did not affect BCG effectiveness. Nonetheless, another study of BCG booster vaccine candidates in $\mathrm{Mtb}$-infected BALB/c mice showed an association between lower $\mathrm{BL}$ and a higher ratio of $\mathrm{CD}^{+}$to $\mathrm{CD}^{+}{ }^{+} \mathrm{FoxP}^{+}$in the lungs (57).

\section{Tregs in Human TB}

The importance of the phenotypic markers used to define Tregs, discussed at the beginning of this review, is highlighted in the work carried out by Zewdie et al. (58), who found that while $\mathrm{CD} 4^{+} \mathrm{CD} 25^{+/ h i}$ T-cell frequencies were higher in patients with active TB than individuals with LTBI, there were no differences in the frequency of $\mathrm{CD} 4^{+} \mathrm{CD} 25^{+} \mathrm{CD} 127^{\mathrm{lo}}$, $\mathrm{CD} 4^{+} \mathrm{CD} 25^{+} \mathrm{FoxP}^{+}$, or $\mathrm{CD} 4^{+} \mathrm{CD} 25^{+} \mathrm{FoxP}^{+} \mathrm{CD} 127^{\text {lo }} \mathrm{T}$ cells.
A similar finding had been noted before by Wergeland et al. (59), who found lower levels of CD ${ }^{+} \mathrm{CD} 25^{+} \mathrm{CD} 127^{-}$Tregs, but not of $\mathrm{CD}^{+}{ }^{+} \mathrm{CD} 25^{+}$FoxP3 ${ }^{+}$Tregs, in healthy controls compared to subjects with either active TB or LTBI. The specific parent population in the hierarchy of the analysis is also relevant. For example, in one study the percentage of $\mathrm{CD} 4^{+} \mathrm{CD} 25^{\text {hi }}$ cells expressing FoxP3 was the same in both study groups, but the percentage of $\mathrm{CD} 4{ }^{+} \mathrm{CD} 25^{\text {hi }} \mathrm{FoxP} 3^{+}$relative to total $\mathrm{CD} 4^{+}$cells was significantly different between healthy donors and patients with pulmonary TB (PTB) (60).

The first association between Tregs and TB patients was shown by Guyot-Revol et al. (61). Before starting treatment, TB patients had higher frequencies of $\mathrm{CD} 4{ }^{+} \mathrm{CD} 25^{\text {hi }}$ Tregs and a higher expression of FoxP3 in PBMCs compared to healthy controls. This difference has been shown in various cohorts summarized below.

Burl et al. (62) performed a study of FoxP3 gene expression in TB contacts. They found that non-infected contacts (ELISPOTand tuberculin skin test (TST)-negative) had higher levels of FoxP3 mRNA in blood than Mtb-infected contacts (ELISPOTand TST-positive), but lower levels than patients with active TB. They hypothesize that this may be due to the sequestering of Tregs in the lungs at early stages of infection and their subsequent reappearance in the periphery. However, it has been shown that in patients with PTB, but not in LTBI subjects, Treg levels are higher in bronchoalveolar lavage (BAL) than in blood (63). FoxP3 expression was detected in the immunohistochemical analysis of Mtb-infected lymph nodes 
(LN) (60). In patients with $\mathrm{LN} \mathrm{TB}$, there were higher levels of Tregs and activated $\mathrm{CD}^{+} \mathrm{T}$ cells among lymph node mononuclear cells than among PBMCs (64). Higher levels of Tregs have also been described in pleural effusion fluid compared to PBMCs $(65,66)$.

Chiacchio et al. found no differences in Treg levels unless they did an Mtb-specific in vitro stimulation. After 1- or 6-day stimulation with Mtb-specific RD1 proteins, TB patients had higher levels of both $\mathrm{CD} 4{ }^{+} \mathrm{CD} 25^{\text {hi }} \mathrm{FoxP} 3^{+}$and $\mathrm{CD} 4{ }^{+} \mathrm{CD} 25^{\text {hi }} \mathrm{CD} 39^{+}$Tregs than healthy controls (29). In PBMCs stimulated with the mycobacterial antigens PPD, ESAT-6, or CFP-10, the characterization of activated $\mathrm{CD} 4^{+} \mathrm{T}$ cells showed a higher percentage of $\mathrm{CD} 4{ }^{+} \mathrm{CD} 25^{+} \mathrm{CD} 134^{+}$-expressing $\mathrm{CD} 39$ in active TB than in LTBI. In line with the high expression of this immunosuppressive molecule, the ratio of IL-10 to IFN- $\gamma$ production was increased in cell cultures from active TB cases compared to LTBI (67). The characterization of BCG-stimulated whole blood in a pediatric TB population supports these results: Tregs were higher in TB than in healthy controls (68). Moreover, the analysis of cytokines in the supernatants of these cultures showed higher levels of pro-inflammatory mediators in healthy controls. When comparing PTB to extrapulmonary TB, the authors found that Tregs could not be used to distinguish the two populations. Interestingly, however, when they looked at Treg levels after 6 months of treatment, they found that children with PTB had a significant increase but those with extrapulmonary TB did not.

$\mathrm{Xu}$ et al. (69) studied PTB patients at the time of diagnosis (sputum smear positive) and the same subjects after 3 weeks of treatment (sputum smear negative). Like Whittaker et al. (68), they found that with the course of treatment, both Treg frequency in PBMCs and plasma levels of IL-10 increased, and at the same time correlated negatively with plasma levels of IL-17. In contrast, Singh et al. (70) described a positive correlation between Tregs and BL in sputum.

A follow-up study performed over 9 months, comprising the 6 months of treatment, showed that Tregs continued to increase until month 4, but later decreased until levels matched those of healthy controls (71). Two similar studies with 2- or 6-month follow-up periods during treatment showed that Treg levels were higher in pulmonary TB patients than healthy controls, and decreased with chemotherapy, with no transient increase $(72,73)$. Agrawal et al. (74) suggest that this could be a way to monitor treatment success or failure, since the one case of failure they had in a new cohort had had an increase in Treg levels. In fact, the lack of Treg decrease with treatment has been linked to multidrug-resistant TB (MDR-TB) and has been proposed for monitoring purposes (70). Nevertheless, the PBMCs stimulus with BCG antigens showed higher levels of Tregs in TB patients but also in cured individuals when comparing with LTBI (75). Prophylactic treatment of LTBI subjects resulted in augmented levels of Tregs with the phenotype $\mathrm{CD} 4^{+} \mathrm{CD} 25^{+} \mathrm{FoxP} 3^{+}$, but no differences were seen in levels of CD ${ }^{+} \mathrm{CD} 25^{+} \mathrm{CD} 127^{-}$(59). However, the latter phenotype was the one that differentiated between control subjects and those with TB or LTBI.

Regarding the importance of the balance between pro- and anti-inflammatory responses, Luo et al. (76) found that not only were Treg percentages higher in patients with active TB than in those with LTBI or controls, but so were Th17 cell percentages (and their corresponding cytokines in plasma). Furthermore, LTBI patients presented higher levels of Tregs and IL-10 than healthy controls. Conversely, Chen et al. (65) found that the blood of TB patients had higher levels of FoxP3 ${ }^{+} \mathrm{CD} 4^{+}$cells but lower levels of IL-17-producing $\mathrm{CD}^{+}{ }^{+}$cells compared to that

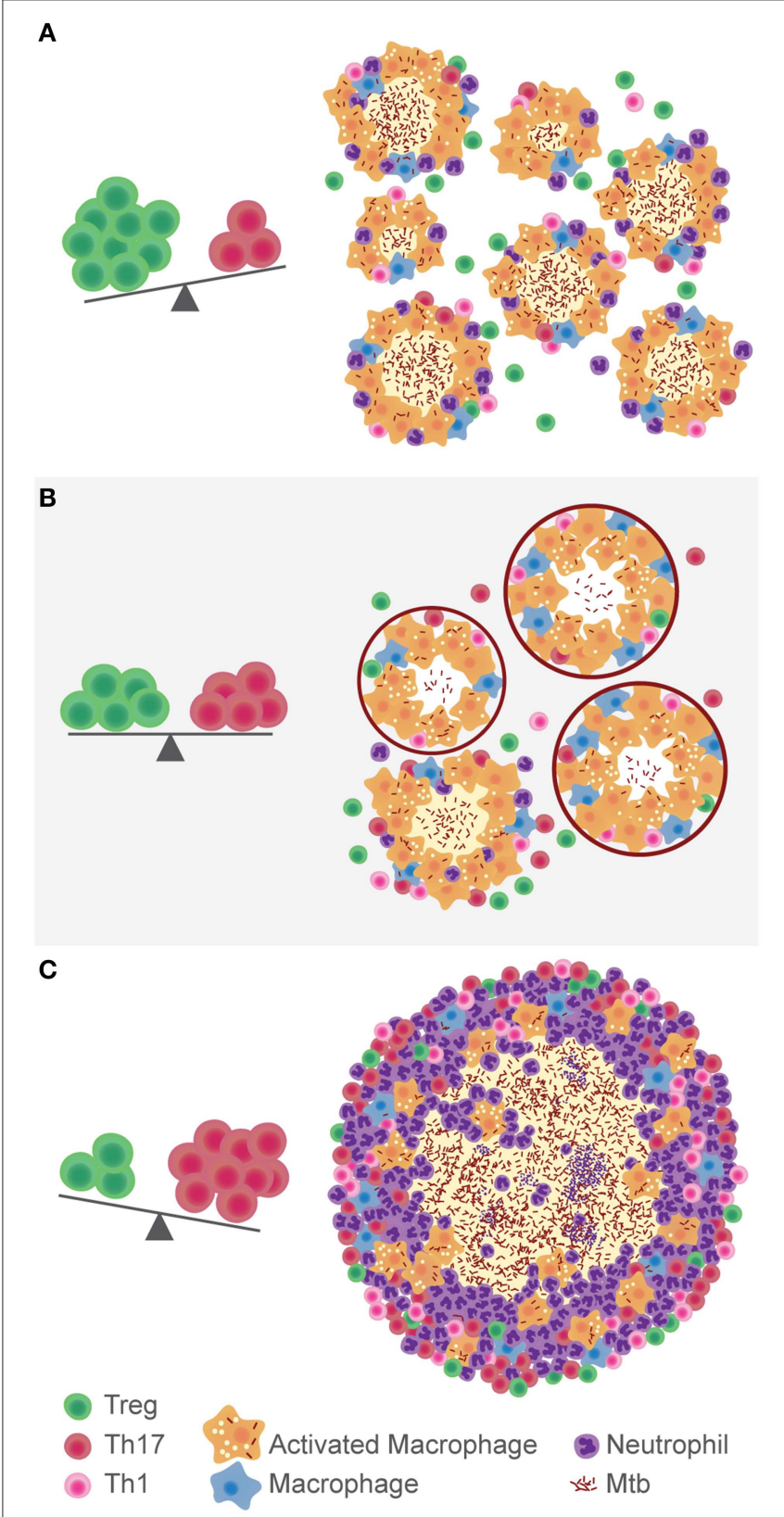

FIGURE 1 | Hypothesis on the role of the balance between Tregs and Th17 cells in the development of TB. In a context of immunosuppression, where Tregs are predominant over Th17, Mtb disseminates more easily (A). The immune balance between these populations gives place to the encapsulation and control of lung lesions (B). If there is a high Th17 response, inflammation and neutrophils recruitment fuel the growth of the granuloma and development of TB (C). 
of both healthy donors and LTBI subjects. Nevertheless, IL-6 and TGF- $\beta$ plasma levels were higher, a fact typically linked to induction of the Th17 population. The authors suggest a possible explanation in terms of reduced expression of IL-6R CD $4^{+}$cells caused by Mtb.

Pang et al. (77) also found a higher frequency of Tregs in blood in active TB than in LTBI or healthy controls. When they took a closer look at this group of subjects, they observed that Treg levels were higher in patients with a positive sputum smear and in those with cavitary PTB. A different approach was taken by Lim et al. (78), who looked into the differences between drug-sensitive TB and MDR-TB. They did not find significant differences between these groups, but once again Treg levels were higher in active TB than in healthy controls. Treg frequency was higher in smear-positive patients and did not correlate with radiological extent or cavitation. MDR-TB patients whose sputum results had remained negative for at least 6 months had Treg levels similar to those of healthy controls. More recently, research with the same target population showed that MDR-TB patients had higher Treg frequencies than those with drug-sensitive $\mathrm{TB}$, and this was supported by blood levels of regulatory cytokines IL-10, and TGF- $\beta$ (79). The same differences were found when looking at $\mathrm{CD} 4{ }^{+} \mathrm{CD} 25^{+}$cells expressing the co-stimulatory receptors PD-1 or CTLA-4. Similarly, patients with MDR-TB had higher (though not significantly higher) percentages of $\mathrm{CD} 4^{+} \mathrm{CD} 25^{+}$Tregs in blood and higher IL-10 levels in serum than those with drugsensitive TB (80). We note that neither of these studies provided any data on the extent of pulmonary disease, which usually is worse in MDR-TB (81).

\section{CONCLUDING REMARKS}

It is clear that the balance between pro- and anti-inflammatory responses to Mtb infection is important in the development of the disease and should be further studied.

Research performed on animal models is a useful way of focusing on different aspects in the progression of Mtb infection and their relationship with Tregs. One of the main advantages of these studies is the possibility of easily looking into the site of infection and lymphoid tissues. They also provide the possibility of modulating many of the involved actors to further understand the mechanisms behind Mtb infection. In this sense, the development of knock outs and monoclonal antibodies has been of great help. However, using animal models has obvious limitations when the time comes to translate findings to human TB. It is crucial to set appropriate objectives in each model and to contextualize results.

Most work carried out on animal models describes an increase in Treg levels as Mtb infection progresses. Experimental depletion of $\mathrm{CD} 25+\mathrm{T}$ cells as a proxy of Treg deletion, even being a rough approach to the issue, resulted in worse pathology or higher bacillary load, arguing they have in fact a detrimental role for the host. Nonetheless, higher frequencies of Tregs have been related to less susceptible mouse strains and better lung pathology or non-progression toward disease in NHP.
There have been many studies carried out in patient cohorts, with the main limitation being that they are mostly based on PBMCs. It has been shown that in TB patients Treg levels are higher at the site of infection, so the study of PBMCs may seem somewhat inaccurate. Furthermore, even when contact trace studies may give an approximate time of exposure to Mtb, the exact steps of infection are hard to elucidate in human TB. Longitudinal studies, the ones that could really shed more light on whether Tregs have a beneficial or detrimental role in TB, are rare. Potentially, monitoring of Tregs as an exploratory endpoint in future prospective cohort study addressing progression from LTBI toward active TB could be of interest to solve this question.

Many studies suggest the potential use of Tregs as a diagnostic method for active TB. In general, Tregs are higher in active TB than in LTBI or healthy controls. However, the difference between LTBI and non-infected persons is less clear. So far this seems unrealistic and much work remains to be done in this context, not only because of the everlasting issue of Treg phenotyping, but also because it is difficult to set a cut-off value for this parameter. Tregs have also been suggested as a way of monitoring the effectiveness of treatment. This option is even more challenging as direct correlation between bacillary load and Treg has never been done in the context of chemotherapy.

All in all, the research carried out so far on Tregs and TB suggests it is not a black-and-white issue. In a setting of excessive inflammation, they would appear to be beneficial for the host. However, their immunosuppressive role could also be advantageous for the pathogen. It is most probably a matter of balance between both responses (Figure 1). Mtb is a slow growing pathogen that generates a delayed immune response. The scale tipped toward Tregs at this instance would play in favor of the bacillus, allowing its dissemination, and intracellular growth. Also, the relatively low Th17 response would delay the recruitment of neutrophils to the site of infection. However, in the opposite scenario, a low Treg response would benefit the onset of an excessive inflammatory response, characteristic of pulmonary TB. Ideally, a balanced situation in which the immune system controls Mtb growth without generating tissue damage, would allow the encapsulation of the small granulomas and limit Mtb spread. More efforts should be done on analyzing not just the regulatory response against $\mathrm{Mtb}$, but rather its equilibrium with the pro-inflammatory response, especially Th17.

\section{AUTHOR CONTRIBUTIONS}

PC and P-JC conceptualized the review. PC provided an initial draft. P-JC performed the final edits.

\section{FUNDING}

This work was supported by the Plan Nacional I + D + I co-financed by ISCIII-Subdirección General de Evaluación and Fondo-EU de Desarrollo Regional (FEDER) through PC contract IFI14/00015 and project PI14/01038. The project leading to these results has received funding from la Caixa Foundation (ID 100010434), under agreement LCF/PR/GN16/10290002. 


\section{REFERENCES}

1. World Health Organization. Global Tuberculosis Report 2018. Geneva. (2018).

2. Houben RMGJ, Dodd PJ. The global burden of latent tuberculosis infection: a re-estimation using mathematical modelling. PLoS Med. (2016) 13:e1002152. doi: 10.1371/journal.pmed.1002152

3. Casadevall A, Pirofski L. The damage-response framework of microbial pathogenesis. Nat Rev Microbiol. (2003) 1:17-24. doi: 10.1038/nrmicro732

4. Cardona P-J. Revisiting the natural history of tuberculosis. The inclusion of constant reinfection, host tolerance, and damage-response frameworks leads to a better understanding of latent infection and its evolution towards active disease. Arch Immunol Ther Exp. (2010) 58:7-14. doi: 10.1007/s00005-009-0062-5

5. Tobin DM, Vary JC, Ray JP, Walsh GS, Dunstan SJ, Bang ND, et al. The lta4h locus modulates susceptibility to mycobacterial infection in zebrafish and humans. Cell. (2010) 140:717-30. doi: 10.1016/j.cell.2010.02.013

6. Tobin DM, Roca FJ, Oh SF, McFarland R, Vickery TW, Ray JP, et al. Host genotype-specific therapies can optimize the inflammatory response to mycobacterial infections. Cell. (2012) 148:434-46. doi: 10.1016/j.cell.2011.12.023

7. Medzhitov R, Schneider DS, Soares MP. Disease tolerance as a defense strategy. Science. (2012) 335:936-41. doi: 10.1126/science.1214935

8. Moore KW, de Waal Malefyt R, Coffman RL, O'Garra A. Interleukin10 and the Interleukin-10 receptor. Annu Rev Immunol. (2002) 19:683765. doi: 10.1146/annurev.immunol.19.1.683

9. Nakamura K, Kitani A, Fuss I, Pedersen A, Harada N, Nawata H, et al. TGF-beta 1 plays an important role in the mechanism of CD4+CD25+ regulatory $\mathrm{T}$ cell activity in both humans and mice. J Immunol. (2004) 172:834-42. doi: 10.4049/jimmunol.172.2.834

10. Collison LW, Workman CJ, Kuo TT, Boyd K, Wang Y, Vignali KM, et al. The inhibitory cytokine IL-35 contributes to regulatory T-cell function. Nature. (2007) 450:566-9. doi: 10.1038/nature06306

11. Oderup C, Cederbom L, Makowska A, Cilio CM, Ivars F. Cytotoxic $\mathrm{T}$ lymphocyte antigen-4-dependent down-modulation of costimulatory molecules on dendritic cells in CD4+ CD25+ regulatory T-cell-mediated suppression. Immunology. (2006) 118:240-9. doi: 10.1111/j.1365-2567.2006.02362.x

12. Grossman WJ, Verbsky JW, Barchet W, Colonna M, Atkinson JP, Ley TJ. Human $\mathrm{T}$ regulatory cells can use the perforin pathway to cause autologous target cell death. Immunity. (2004) 21:589-601. doi: 10.1016/j.immuni.2004.09.002

13. Pandiyan P, Reed J, Zheng L, Lenardo MJ, Ishihara S. CD4+CD25+Foxp3+ regulatory $\mathrm{T}$ cells induce cytokine deprivation-mediated apoptosis of effector CD4+ T cells. Nat Immunol. (2007) 8:1353-62. doi: 10.1038/ni1536

14. Kanamori M, Nakatsukasa $\mathrm{H}$, Okada $\mathrm{M}, \mathrm{Lu} \mathrm{Q}$, Yoshimura A. Induced regulatory T cells: their development, stability, and applications. Trends Immunol. (2016) 37:803-11. doi: 10.1016/j.it.2016.08.012

15. Thornton AM, Korty PE, Tran DQ, Wohlfert EA, Murray PE, Belkaid $\mathrm{Y}$, et al. Expression of helios, an ikaros transcription factor family member, differentiates thymic-derived from peripherally induced Foxp3+ T regulatory cells. J Immunol. (2010) 184:3433-41. doi: 10.4049/jimmunol. 0904028

16. Weiss JM, Bilate AM, Gobert M, Ding Y, Curotto de Lafaille MA, Parkhurst $\mathrm{CN}$, et al. Neuropilin 1 is expressed on thymus-derived natural regulatory $\mathrm{T}$ cells, but not mucosa-generated induced Foxp3 + T reg cells. J Exp Med. (2012) 209:1723-42. doi: 10.1084/jem.20120914

17. Marie JC, Letterio JJ, Gavin M, Rudensky AY. TGF- $\beta 1$ maintains suppressor function and Foxp3 expression in CD4 + CD25 + regulatory T cells . J Exp Med. (2005) 201:1061-7. doi: 10.1084/jem.20042276

18. Yu Y, Ma X, Gong R, Zhu J, Wei L, Yao J. Recent advances in CD8+ regulatory t cell research. (Review). Oncol Lett. (2018) 15:818794. doi: $10.3892 /$ ol.2018.8378

19. Zola H, Swart B, Banham A, Barry S, Beare A, Bensussan A, et al. CD molecules 2006 - human cell differentiation molecules. J Immunol Methods. (2007) 319:1-5. doi: 10.1016/j.jim.2006.11.001

20. Fontenot JD, Gavin MA, Rudensky AY. Foxp3 programs the development and function of CD4+CD25+ regulatory T cells. J Immunol. (2003) 198:98692. doi: $10.1038 /$ ni904
21. Bacchetta R, Passerini L, Gambineri E, Dai M, Allan SE, Perroni L, et al. Defective regulatory and effector $\mathrm{T}$ cell functions in patients with FOXP3 mutations. J Clin Invest. (2006) 116:1713-22. doi: 10.1172/JCI25112

22. Brunkow ME, Jeffery EW, Hjerrild KA, Paeper B, Clark LB, Yasayko SA, et al. Disruption of a new forkhead/winged-helix protein, scurfin, results in the fatal lymphoproliferative disorder of the scurfy mouse. Nat Genet. (2001) 27:68-73. doi: $10.1038 / 83784$

23. Devaud C, Darcy PK, Kershaw MH. Foxp3 expression in T regulatory cells and other cell lineages. Cancer Immunol Immunother. (2014) 63:86976. doi: 10.1007/s00262-014-1581-4

24. Vieira PL, O'Garra A, Barrat FJ, Minaee S, Barthlott T, Christensen JR, et al. IL-10-Secreting regulatory T cells do not express foxp3 but have comparable regulatory function to naturally occurring $\mathrm{CD} 4+\mathrm{CD} 25+$ regulatory $\mathrm{T}$ cells. $J$ Immunol. (2004) 172:5986-93. doi: 10.4049/jimmunol.172.10.5986

25. Seddiki N, Santner-Nanan B, Martinson J, Zaunders J, Sasson S, Landay A, et al. Expression of interleukin. (IL)-2 and IL-7 receptors discriminates between human regulatory and activated T cells. J Exp Med. (2006) 203:1693700. doi: $10.1084 /$ jem. 20060468

26. Liu W, Putnam AL, Xu-Yu Z, Szot GL, Lee MR, Zhu S, et al. CD127 expression inversely correlates with FoxP3 and suppressive function of human CD4+ T reg cells. J Exp Med. (2006) 203:1701-11. doi: 10.1084/jem.20060772

27. Borsellino G, Kleinewietfeld M, Di Mitri D, Sternjak A, Diamantini A, Giometto R, et al. Expression of ectonucleotidase CD39 by Foxp3+ treg cells: hydrolysis of extracellular ATP and immune suppression. Blood. (2007) 110:1225-32. doi: 10.1182/blood-2006-12-064527

28. Gu J, Ni X, Pan X, Lu H, Lu Y, Zhao J, et al. Human CD39hi regulatory T cells present stronger stability and function under inflammatory conditions. Cell Mol Immunol. (2017) 14:521-8. doi: 10.1038/cmi.2016.30

29. Chiacchio T, Casetti R, Butera O, Vanini V, Carrara S, Girardi $\mathrm{E}$, et al. Characterization of regulatory $\mathrm{T}$ cells identified as CD4(+)CD25(high)CD39(+) in patients with active tuberculosis. Clin Exp Immunol. (2009) 156:463-70. doi: 10.1111/j.1365-2249.2009.03908.x

30. Ouyang W, Kolls JK, Zheng Y. The biological functions of $\mathrm{T}$ helper 17 cell effector cytokines in inflammation. Immunity. (2008) 28:45467. doi: 10.1016/j.immuni.2008.03.004

31. Ivanov II, McKenzie BS, Zhou L, Tadokoro CE, Lepelley A, Lafaille JJ, et al. The orphan nuclear receptor RORgammat directs the differentiation program of proinflammatory IL-17+ T helper cells. Cell. (2006) 126:112133. doi: $10.1016 /$ j.cell.2006.07.035

32. Veldhoen M, Hocking RJ, Atkins CJ, Locksley RM, Stockinger B. TGF $\beta$ in the context of an inflammatory cytokine milieu supports de novo differentiation of IL-17-producing T cells. Immunity. (2006) 24:17989. doi: 10.1016/j.immuni.2006.01.001

33. Zhou L, Lopes JE, Chong MMW, Ivanov II, Min R, Victora GD, et al. TGF-beta-induced Foxp3 inhibits $\mathrm{T}(\mathrm{H}) 17$ cell differentiation by antagonizing RORgammat function. Nature. (2008) 453:236-40. doi: 10.1038/nature06878

34. Fletcher JM, Lonergan R, Costelloe L, Kinsella K, Moran B, O'Farrelly C, et al. CD39+Foxp3+ regulatory $\mathrm{T}$ Cells suppress pathogenic Th17 cells and are impaired in multiple sclerosis. J Immunol. (2009) 183:760210. doi: 10.4049/jimmunol.0901881

35. Abdolahi M, Yavari P, Honarvar NM, Bitarafan S, Mahmoudi M, SaboorYaraghi AA. Molecular mechanisms of the action of vitamin A in Th17/treg axis in multiple sclerosis. J Mol Neurosci. (2015) 57:60513. doi: $10.1007 / \mathrm{s} 12031-015-0643-1$

36. Kim EY, Moudgil KD. Immunomodulation of autoimmune arthritis by pro-inflammatory cytokines. Cytokine. (2017) 98:87-96. doi: 10.1016/j.cyto.2017.04.012

37. Dwyer KM, Hanidziar D, Putheti P, Hill PA, Pommey S, McRae JL, et al. Expression of CD39 by human peripheral blood CD4+CD25+T cells denotes a regulatory memory phenotype. Am J Transplant. (2010) 10:241020. doi: $10.1111 /$ j.1600-6143.2010.03291.x

38. Frydrychowicz M, Boruczkowski M, Kolecka-Bednarczyk A, Dworacki G. The dual role of treg in cancer. Scand J Immunol. (2017) 86:43643. doi: $10.1111 /$ sji.12615

39. Rad R, Brenner L, Bauer S, Schwendy S, Layland L, da Costa CP, et al. CD25+/Foxp3+ $\mathrm{T}$ cells regulate gastric inflammation and helicobacter pylori colonization in vivo. Gastroenterology. (2006) 131:525-37. doi: 10.1053/j.gastro.2006.05.001 
40. Karkhah A, Javanian M, Ebrahimpour S. The role of regulatory T cells in immunopathogenesis and immunotherapy of viral infections. Infect Genet Evol. (2018) 59:32-7. doi: 10.1016/j.meegid.2018.01.015

41. Stephen-Victor E, Bosschem I, Haesebrouck F, Bayry J. The yin and yang of regulatory $\mathrm{T}$ cells in infectious diseases and avenues to target them. Cell Microbiol. (2017) 19:e12746. doi: 10.1111/cmi.12746

42. Shang S, Harton M, Tamayo MH, Shanley C, Palanisamy GS, Caraway $\mathrm{M}$, et al. Increased Foxp3 expression in guinea pigs infected with W-Beijing strains of M. tuberculosis. Tuberculosis. (2011) 91:378-85. doi: 10.1016/j.tube.2011.06.001

43. Kato-Maeda M, Shanley CA, Ackart D, Jarlsberg LG, Shang S, ObregonHenao A, et al. Beijing sublineages of Mycobacterium tuberculosis differ in pathogenicity in the guinea pig. Clin Vaccine Immunol. (2012) 19:122737. doi: 10.1128/CVI.00250-12

44. Green AM, Mattila JT, Bigbee CL, Bongers KS, Lin PL, Flynn JL. CD4 + Regulatory $\mathrm{T}$ cells in a cynomolgus macaque model of Mycobacterium tuberculosis infection. J Infect Dis. (2010) 202:533-41. doi: 10.1086/654896

45. Chen CY, Huang D, Yao S, Halliday L, Zeng G, Wang RC, et al. IL2 Simultaneously expands Foxp3 $+\mathrm{T}$ regulatory and $\mathrm{T}$ effector cells and confers resistance to severe tuberculosis. (TB): implicative treg-T effector cooperation in immunity to TB. J Immunol. (2012) 188:427888. doi: 10.4049/jimmunol.1101291

46. Ozeki Y, Sugawara I, Udagawa T, Aoki T, Osada-Oka M, Tateishi Y, et al. Transient role of CD4+CD25+ regulatory $\mathrm{T}$ cells in mycobacterial infection in mice. Int Immunol. (2010) 22:179-89. doi: 10.1093/intimm/dxp126

47. Scott-Browne JP, Shafiani S, Tucker-Heard G, Ishida-Tsubota K, Fontenot JD, Rudensky AY, et al. Expansion and function of Foxp3-expressing $\mathrm{T}$ regulatory cells during tuberculosis. J Exp Med. (2007) 204:215969. doi: 10.1084/jem.20062105

48. Quinn KM, McHugh RS, Rich FJ, Goldsack LM, De Lisle GW, Buddle BM, et al. Inactivation of CD4+CD25+ regulatory T cells during early mycobacterial infection increases cytokine production but does not affect pathogen load. Immunol Cell Biol. (2006) 84:467-74. doi: 10.1111/j.1440-1711.2006.01460.x

49. Cardona P, Marzo-Escartín E, Tapia G, Díaz J, García V, Varela I, et al. Oral administration of heat-killed mycobacterium manresensis delays progression toward active tuberculosis in $\mathrm{C} 3 \mathrm{HeB} / \mathrm{FeJ}$ mice. Front Microbiol. (2016) 6:47. doi: 10.3389/fmicb.2015.01482

50. Kapina MA, Rubakova EI, Majorov KB, Logunova NN, Apt AS. Capacity of lung stroma to educate dendritic cells inhibiting mycobacteria-specific Tcell response depends upon genetic susceptibility to tuberculosis. PLoS ONE. (2013) 8:1-8. doi: 10.1371/journal.pone.0072773

51. Shafiani S, Tucker-Heard G, Kariyone A, Takatsu K, Urdahl KB. Pathogenspecific regulatory $\mathrm{T}$ cells delay the arrival of effector $\mathrm{T}$ cells in the lung during early tuberculosis. J Exp Med. (2010) 207:1409-20. doi: 10.1084/jem.20091885

52. Shafiani S, Dinh C, Ertelt JM, Moguche AO, Siddiqui I, Smigiel KS, et al. Pathogen-specific treg cells expand early during Mycobacterium tuberculosis infection but are later eliminated in response to interleukin-12. Immunity. (2013) 38:1261-70. doi: 10.1016/j.immuni.2013.06.003

53. McBride A, Konowich J, Salgame P. Host defense and recruitment of Foxp3 $+\mathrm{T}$ regulatory cells to the lungs in chronic Mycobacterium tuberculosis infection requires toll-like receptor 2. PLoS Pathog. (2013) 9:e1003397. doi: 10.1371/journal.ppat.1003397

54. Leepiyasakulchai C, Ignatowicz L, Pawlowski A, Källenius G, Sköld M. Failure to recruit anti-inflammatory CD103+ dendritic cells and a diminished CD4+ Foxp3+ regulatory $\mathrm{T}$ cell pool in mice that display excessive lung inflammation and increased susceptibility to Mycobacterium tuberculosis. Infect Immun. (2012) 80:1128-39. doi: 10.1128/IAI.05552-11

55. Luo Y, Ma X, Liu X, Lu X, Niu H, Yu H, et al. IL-28B down-regulates regulatory $t$ cells but does not improve the protective immunity following tuberculosis subunit vaccine immunization. Int Immunol. (2016) 28:7785. doi: 10.1093/intimm/dxv061

56. Quinn KM, Rich FJ, Goldsack LM, de Lisle GW, Buddle BM, Delahunt B, et al. Accelerating the secondary immune response by inactivating CD4+CD25+ T regulatory cells prior to BCG vaccination does not enhance protection against tuberculosis. Eur J Immunol. (2008) 38:695-705. doi: 10.1002/eji.200737888

57. Fedatto PF, Sérgio CA, Paula MOE, Gembre AF, Franco LH, Wowk PF, et al. Protection conferred by heterologous vaccination against tuberculosis is dependent on the ratio of CD4+/CD4+Foxp3+cells. Immunology. (2012) 137:239-48. doi: 10.1111/imm.12006

58. Zewdie M, Howe R, Hoff ST, Doherty TM, Getachew N, Tarekegne A, et al. Exvivo characterization of regulatory $\mathrm{T}$ cells in pulmonary tuberculosis patients, latently infected persons, and healthy endemic controls. Tuberculosis. (2016) 100:61-8. doi: 10.1016/j.tube.2016.06.007

59. Wergeland I, Amus J, Dyrhol-Riise AM. T regulatory cells and immune activation in Mycobacterium tuberculosis infection and the effect of preventive therapy. Scand J Immunol. (2011) 73:234-42. doi: 10.1111/j.1365-3083.2010.02496.x

60. Chen X, Zhou B, Li M, Deng Q, Wu X, Le X, et al. CD4+CD25+FoxP3+ regulatory $\mathrm{T}$ cells suppress Mycobacterium tuberculosis immunity in patients with active disease. Clin Immunol. (2007) 123:509. doi: 10.1016/j.clim.2006.11.009

61. Guyot-Revol V, Innes JA, Hackforth S, Hinks T, Lalvani A. Regulatory T cells are expanded in blood and disease sites in patients with tuberculosis. Am J Respir Crit Care Med. (2006) 173:803-10. doi: 10.1164/rccm.200508-1294OC

62. Burl S, Hill PC, Jeffries DJ, Holland MJ, Fox A, Lugos MD, et al. FOXP3 gene expression in a tuberculosis case contact study. Clin Exp Immunol. (2007) 149:117-22. doi: 10.1111/j.1365-2249.2007.03399.x

63. Semple PL, Binder AB, Davids M, Maredza A, Van Zyl-Smit RN, Dheda K. Regulatory T cells attenuate mycobacterial stasis in alveolar and blood-derived macrophages from patients with tuberculosis. Am J Respir Crit Care Med. (2013) 187:1249-58. doi: 10.1164/rccm.201210-1934OC

64. Sahmoudi K, Abbassi H, Bouklata N, El Alami MN, Sadak A, Burant $\mathrm{C}$, et al. Immune activation and regulatory $\mathrm{T}$ cells in Mycobacterium tuberculosis infected lymph nodes. BMC Immunol. (2018) 19:1-7. doi: 10.1186/s12865-018-0266-8

65. Chen X, Zhang M, Liao M, Graner MW, Wu C, Yang Q, et al. Reduced Th17 response in patients with tuberculosis correlates with IL-6R expression on CD4+T cells. Am J Respir Crit Care Med. (2010) 181:73442. doi: 10.1164/rccm.200909-1463OC

66. Arram EO, Hassan R, Saleh M. Increased frequency of CD4+CD25+FoxP3+ circulating regulatory T cells (Treg) in tuberculous patients. Egypt J Chest Dis Tuberc. (2014) 63:167-72. doi: 10.1016/j.ejcdt.2013.10.013

67. Kim K, Perera R, Tan DBA, Fernandez S, Seddiki N, Waring J, et al. Circulating mycobacterial-reactive CD4+ T cells with an immunosuppressive phenotype are higher in active tuberculosis than latent tuberculosis infection. Tuberculosis. (2014) 94:494-501. doi: 10.1016/j.tube.2014.07.002

68. Whittaker E, Nicol M, Zar HJ, Kampmann B. Regulatory T cells and proinflammatory responses predominate in children with tuberculosis. Front Immunol. (2017) 8:448. doi: 10.3389/fimmu.2017.00448

69. Xu L, Cui G, Jia H, Zhu Y, Ding Y, Chen J, et al. Decreased IL-17 during treatment of sputum smear-positive pulmonary tuberculosis due to increased regulatory $\mathrm{T}$ cells and IL-10. J Transl Med. (2016) 14:179. doi: 10.1186/s12967-016-0909-6

70. Singh A, Dey AB, Mohan A, Sharma PK, Mitra DK. Foxp3+ Regulatory $\mathrm{T}$ cells among tuberculosis patients: impact on prognosis and restoration of antigen specific IFN- $\gamma$ producing T cells. PLoS ONE. (2012) 7:110. doi: 10.1371 /journal.pone. 0044728

71. Diaz A, Santucci N, Bongiovanni B, D'Attilio L, Massoni C, Lioi S, et al. Increased frequency of $\mathrm{CD} 4+\mathrm{CD} 25+$ FoxP3 $+\mathrm{T}$ regulatory cells in pulmonary tuberculosis patients undergoing specific treatment and its relationship with their immune-endocrine profile. J Immunol Res. (2015) 2015:985302. doi: 10.1155/2015/985302

72. Jackson-Sillah D, Cliff JM, Mensah GI, Dickson E, Sowah S, Tetteh JKA, et al. Recombinant ESAT-6-CFP10 fusion protein induction of Th1/Th2 cytokines and FoxP3 expressing treg cells in pulmonary TB. PLoS ONE. (2013) 8:e68121. doi: 10.1371/journal.pone.0068121

73. Agrawal S, Parkash O, Palaniappan AN, Bhatia AK, Kumar S, Chauhan DS, et al. Efficacy of $\mathrm{T}$ regulatory cells, Th17 cells and the associated markers in monitoring tuberculosis treatment response. Front Immunol. (2018) 9:116. doi: 10.3389/fimmu.2018.00157

74. Agrawal S, Parkash O, Palaniappan AN, Bhatia AK, Kumar S, Chauhan $\mathrm{DS}$, et al. The role of $\mathrm{T}$ regulatory cell-associated markers in monitoring tuberculosis treatment completion and failure. Immunol Res. (2018) 66:62031. doi: $10.1007 /$ s12026-018-9022-7 
75. Da Silva MV, Massaro Junior VJ, Machado JR, Silva DAA, Castellano LR, Alexandre PBD, et al. Expression pattern of transcription factors and intracellular cytokines reveals that clinically cured tuberculosis is accompanied by an increase in mycobacterium-specific Th1, Th2, and Th17 cells. Biomed Res Int. (2015) 2015:5-10. doi: 10.1155/2015/59 1237

76. Luo J, Zhang M, Yan B, Zhang K, Chen M, Deng S. Imbalance of Th17 and Treg in peripheral blood mononuclear cells of active tuberculosis patients. Brazil J Infect Dis. (2017) 21:155-61. doi: 10.1016/j.bjid.2016. 10.011

77. Pang H, Yu Q, Guo B, Jiang Y, Wan L, Li J, et al. Frequency of regulatory $\mathrm{T}$-cells in the peripheral blood of patients with pulmonary tuberculosis from Shanxi Province, China. PLoS ONE. (2013) 8:410. doi: 10.1371/journal.pone.0065496

78. Lim HJ, Park JS, Cho YJ, Yoon H Il, Park KU, Lee CT, et al. $\mathrm{CD} 4+$ FoxP3+T regulatory cells in drug-susceptible and multidrugresistant tuberculosis. Tuberculosis. (2013) 93:523-8. doi: 10.1016/j.tube.2013. 06.001

79. Li N, Xie WP, Kong H, Min R, Hu CM, Zhou XB, et al. Enrichment of regulatory T-cells in blood of patients with multidrug-resistant tuberculosis. Int J Tuberc Lung Dis. (2015) 19:1230-8. doi: 10.5588/ijtld. 15.0148
80. Fan R, Xiang Y, Yang L, Liu Y, Chen P, Wang L, et al. Impaired NK cells' activity and increased numbers of $\mathrm{CD} 4+\mathrm{CD} 25+$ regulatory $\mathrm{T}$ cells in multidrug-resistant Mycobacterium tuberculosis patients. Tuberculosis. (2016) 98:13-20. doi: 10.1016/j.tube.2016.02.001

81. Yeom JA, Jeong YJ, Jeon D, Kim K-I, Kim CW, Park HK, et al. Imaging findings of primary multidrug-resistant tuberculosis: a comparison with findings of drug-sensitive tuberculosis. J Comput Assist Tomogr. (2009) 33:956-60. doi: 10.1097/RCT.0b013e31819877ab

Conflict of Interest Statement: The authors declare that the research was conducted in the absence of any commercial or financial relationships that could be construed as a potential conflict of interest.

P-JC is co-founder of two spin-offs related to tuberculosis: Archivel Farma and Manremyc.

Copyright (C) 2019 Cardona and Cardona. This is an open-access article distributed under the terms of the Creative Commons Attribution License (CC BY). The use, distribution or reproduction in other forums is permitted, provided the original author(s) and the copyright owner(s) are credited and that the original publication in this journal is cited, in accordance with accepted academic practice. No use, distribution or reproduction is permitted which does not comply with these terms. 